\title{
Time for Universal Public Distribution System: Food Mountains and Pandemic Hunger in India \\ Swati Narayan
}

Accepted version: 22 November 2021

Published Version: Indian Journal of Human Development, 2021, 15(3)

\begin{abstract}
The latest National Family Health Survey (NFHS 5), indicates that even before the pandemic, child stunting in India was severe and has been deteriorating since 2015. But after the stringent lockdown, there has been an acute increase in impoverishment as governmental food policies have further exacerbated rather than mitigated inequalities. Families eligible under the National Food Security Act (NFSA, 2013) have been provided with double food grain rations during two waves of the pandemic. But nearly 42 percent of India's population without these ration cards have been excluded from any additional food relief from the central government. Simultaneously, India's food grain stocks in government granaries have accumulated to their all-time peak with two years of bumper harvests. Therefore, in light of the acute distress faced by marginalised communities due to the pandemic, this paper analyses the availability of adequate foodgrain stocks and contends that the time is opportune for the universal expansion of the public distribution system.
\end{abstract}

Keywords: COVID-19, Universalisation, Public Distribution System, Food Corporation of India, Hunger

Affiliation: Swati Narayan is a Postdoctoral Associate at Inequality and Human Development Programme at the National Institute of Advanced Studies

Acknowledgements: The author is grateful to Jean Drèze for helpful comments on an earlier version 


\section{Introduction}

India has the world's largest undernourished population (FAOSTAT 2021). Further, children belonging to marginalised castes and tribes are more likely to be underweight (Deshpande \& Ramachandran, 2020; Narayan, 2016; NFHS, 2017). In this scenario, the imposition of one of the most stringent COVID-19 lockdowns in the world (Hale et al., 2020), has acutely exacerbated structural inequalities of caste, class, ethnicity and gender. The second wave of the pandemic has been particularly catastrophic for both lives and livelihoods, and intensified hunger amongst vulnerable communities.

The National Food Security Act, 2013 (NFSA) guarantees subsidised food grains to two of every three Indians each month. Nevertheless, in the last few years, despite burgeoning foodgrain stocks in government granaries, there have been a series of purported starvation deaths (Bhattacharya, 2020; Johari, 2018), especially amongst marginalised castes and tribes (Bhatia, 2018). Further, since the abrupt lockdown in March, more than 200 people have reportedly died of starvation, financial distress and exhaustion (Aman et al., 2020). Most of these families, did not have functional ration cards to purchase subsidised food grains. The latest National Family Health Survey (NFHS), also indicates that in 13 of 17 Indian states, for which data has been released, the proportion of stunted children has worsened or stagnated from 2015 to 2019 (IIPS and MoHFW, 2020).

So, in this scenario, this research will concentrate on two modes of enquiry. On the supply side, this research will estimate projected stocks in government warehouses. Then on the demand side, this analysis will examine the implementation of food security measures, especially in terms of the capability of vulnerable communities to mitigate the impacts of repeated lockdowns. In the context of the pandemic and unprecedented global economic recession, this analysis contends that the time is opportune for the universal expansion of food security protections.

\section{Intersectional Vulnerabilities and Universal Entitlements}

Theoretically, the capabilities approach analyses this paradoxical phenomenon of 'hunger amidst plenty,' due to acute inequalities in food distribution (Drèze \& Sen, 1989a; Sen, 2003). Economists Jean Drèze and Amartya Sen have highlighted the, 'scandalous phenomenon of mounting food stocks against a backdrop of widespread hunger' (Drèze and Sen 2002:336). Despite enactment of a series of legislative entitlements, unfortunately this phenomenon of 'hunger amidst plenty' persists in the midst of the pandemic. 
The strident national and state lockdowns have particularly aggravated multi-dimensional inequalities. Davies defines intersectional vulnerabilities as, 'the interaction between gender, race, and other categories of social difference in individual lives, social practices, institutional arrangements, and cultural ideologies and the outcomes of these interactions in terms of power' (Davis, 2008). Especially given the depth of undernutrition in India, the pandemic has amplified food insecurity amongst vulnerable communities.

However, social crisis as periods of accelerated change often function as policy levers to open unprecedented political windows of opportunity to bolster welfare systems (Beresford, 2016) for their role as 'automatic stabilizers' (Ocampo \& Stiglitz, 2018). The pandemic, in particular, has necessitated a fundamental rethink of citizen-state relations and the need for 'radically transformative, egalitarian and inclusive' policies (Leach et al., 2021).

In India the impact of the contagion has been so severe, that irrespective of the scenario of recessionary contraction of the economy, the pandemic is expected to contribute to half the estimated additional poor globally (Sumner et al., 2020). Estimates indicate that 230 million Indians may have already fallen into poverty (APU, 2021). Therefore, given the severity of the pandemic, coupled with the existing depth of poverty and malnutrition in India, there is an urgent need for a shift in the welfare regime towards universal food entitlements.

Before 1997, India's subsidised public distribution system (PDS) was universally accessible to the entire population through a well-established network of more than 1 million fair price shops. Thereafter, the targeted regime introduced differential prices and entitlements (Khera, 2009). For nearly a decade, the selection criteria to identify eligible 'Below the Poverty Line' families officially remained unaltered, despite significant inclusion and exclusion errors (Hirway, 2003; Khera, 2009; NCAER, 2015; Sundaram, 2003; Swaminathan \& Misra, 2001). With the legal enactment of the NFSA in 2013, the targeted approach continued, albeit with a change in nomenclature and substantial expansion of eligible 'priority' families to include two-thirds of the population. Nevertheless, though exclusion errors have declined overall, they remained substantial in backward states such as Bihar and Jharkhand (Drèze et al., 2015). The series of starvation deaths especially in the poorest states, even after the enactment of the law, also, indicate the inherent flaws of restricted narrow targeting (Banik, 2016; Bedamatta, 2016; NCAER, 2015). Despite their legal eligibility, marginalised communities with intersectional vulnerabilities and weaker socio-political clout are invariably at greater risk of exclusion. With the pandemic, oddly, as a relief measure the central government has provided an additional 5 kilograms of free foodgrain under the Pradhan Mantri Garib Kalyan Anna Yojana (PMGKAY) only for families with 
NFSA 'priority' ration cards, for a limited period. However, families without these ration cards have been largely excluded from central government food security protections. Therefore, the persistence of targeted food policy has exacerbated inequalities.

Instead, especially in a scenario of mass impoverishment, universal programmes are more effective (Ocampo \& Stiglitz, 2018). First, universally justiciable rights-based legislative protections are expected to be more inclusive (Drèze \& Sen, 1989b). Second, the greater political clout of wealthier households in universal programmes is expected to improve accountability (Hirschman, 1970; Sen, 1992) of the public distribution system. On the other hand, programs with limited beneficiaries often have weaker political bases and are more susceptible to rationalisation (Skocpol, 1991). Third, elite capture (Bardhan \& Mookherjee, 2005) and exclusion of poor households (Swaminathan \& Misra, 2001) are greater concerns in targeted systems. Fourth, information asymmetries invariably plague targeted programmes (Madhura Swaminathan 2002). Empirical research also indicate that, 'take-up rates by poor households increase with benefits provided to nonpoor households' (Kochar 2005:233). The experience of several states in expansion and universalisation of the PDS such as Tamil Nadu (Chaudhuri et al., 2015), Odisha (Chatterjee, 2014) and Andhra Pradesh (Dutta \& Ramaswamy, 2001) have also ensured greater inclusion of poor households. Further, in states with relatively well-functioning PDS, lower caste households tend to benefit more (Das \& Basu, 2014). Alternatively, geographical targeting to ensure universal coverage, at least in hunger-prone districts, is also an effective strategy which in the Kalahandi-Bolangir-Koraput (KBK) region of Odisha has ensured improvement in both household food intake and diet quality (Rahman, 2016).

\section{Supply Side: Foodgrain mountains in government granaries}

Since the green revolution, in the sixties, India has attained self-sufficiency with surplus food grain production. India's cereal production has increased 500 percent in seven decades, from 48 million tonnes in 1951 to 292 million tonnes in 2019-2020. However, some states such as Kerala remain deficit states due to their limited sowing area and focus on cash crops. Therefore, since its inception in 1965, the Food Corporation of India (FCI) has been procuring cereals from farmers at minimum support prices (MSP), in order to re-distribute them at subsidised prices to deficit states and impoverished consumers. 


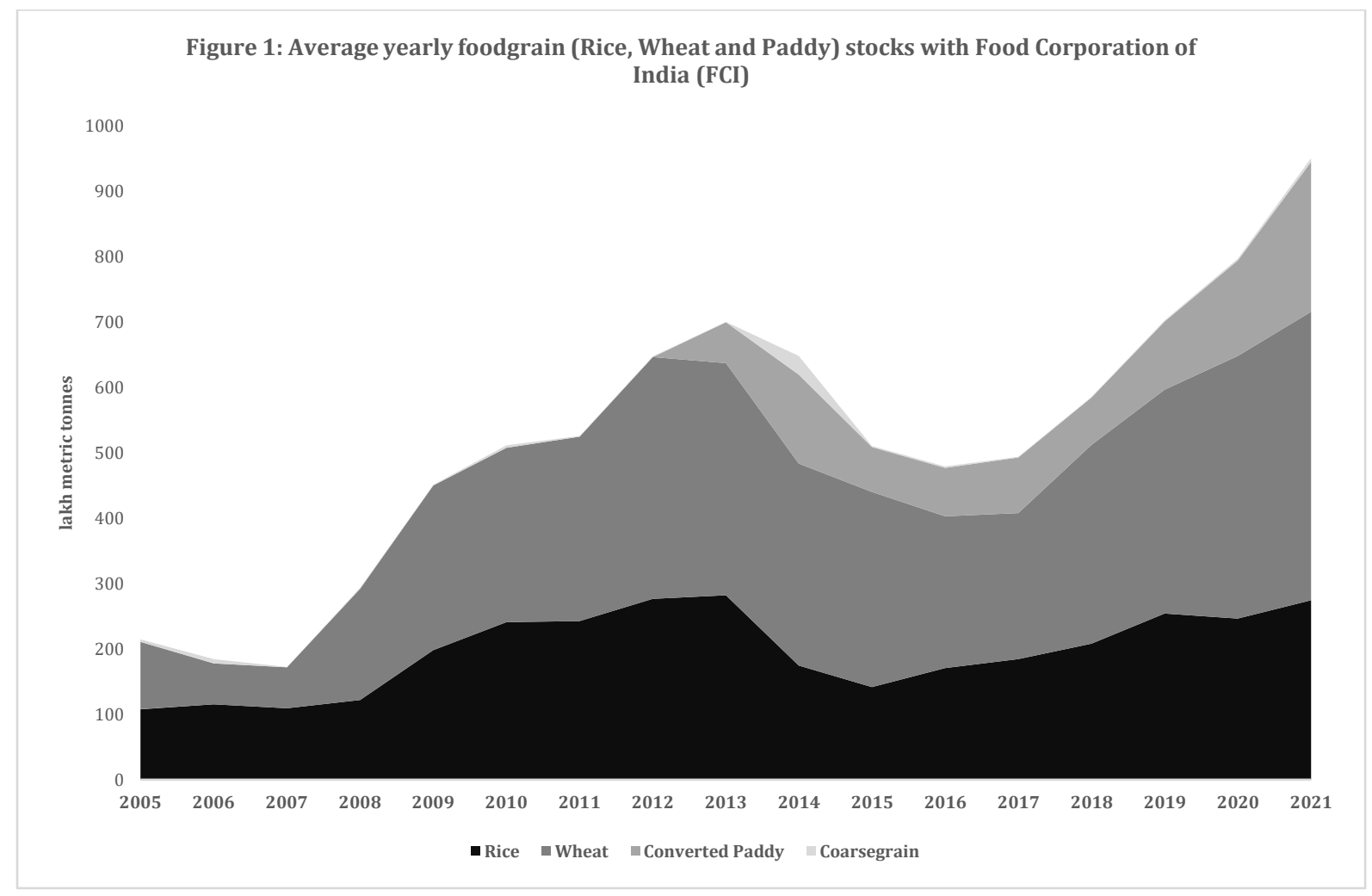

Source: Based on FCI data on stocks in Central Pool for the years 2005-2021

https://fci.gov.in/stocks.php?view=46 (last accessed 4 September 2021)

${ }^{*}$ Converted Paddy is Custom Milled Rice that can be derived with an out-turn ratio of 67 percent from unmilled paddy as the norm specified in the FCI monthly Foodgrain Bulletins. The data on paddy procured has not been made available on the FCI website before 2013

After the harvest, in June 2021 food grain stocks with the FCI were at an all-time peak of 110 million tonnes and exceeded its storage capacity of 81 million tonnes (see Figure 1). Therefore, the prime minister's announcement of free food grains for all Indians with NFSA ration cards, was also a calculated measure to offset rotting of food grains in granaries in the monsoon months (Drèze, 2020). The stocks were so excessive, that the government has even permitted diversion of rice for the production of ethanol for use in alcohol-based hand sanitisers (Hussain and Ranade 2020). Even in May 2021, foodgrain stocks were 3.5 times more the buffer norm (Hussain \& Mohapatra, 2021).

Instead, the additional food grain requirement for universal expansion of the PDS at 5 kilograms per person per month, assuming even an exceptionally high 99 percent offtake (except for 1 percent of income tax payers in the country), can be estimated at approximately 30-31 million tonnes annually in 2021 and 2022 (see Table 1). With the existing stock in August 2021 of 101.5 million tonnes in government warehouses, this expansion can be easily implemented. Further, 
the average annual government procurement in 2019-20 was 86 million tonnes in a year of normal harvests, and 95 million tonnes in 2020-21 with bumper harvests.

\begin{tabular}{|c|c|c|c|c|c|c|c|}
\hline & & \multirow[b]{2}{*}{$\begin{array}{c}\text { FCI } \\
\text { Procurement* }\end{array}$} & \multicolumn{4}{|c|}{ Estimated PDS Distribution with Universal Coverage } & \multirow{2}{*}{$\begin{array}{c}\text { Projected } \\
\text { FCI Stocks = } \\
\text { Previous } \\
\text { Month's (FCI } \\
\text { Stock - PDS } \\
\text { Distribution } \\
\text { J + } \\
\text { Procuremen } \\
\text { t\#\# } \\
\end{array}$} \\
\hline & & & NFSA $^{* *}$ & PMGKAY*** & Universal\# & Total & \\
\hline \multirow{5}{*}{2021} & August & \multirow{5}{*}{482} & 50 & 40 & & 90 & 1015 \\
\hline & September & & 50 & 40 & 30 & 120 & 925 \\
\hline & October & & 50 & 40 & 30 & 120 & 804 \\
\hline & November & & 50 & 40 & 30 & 120 & 684 \\
\hline & December & & 50 & & 30 & 80 & 1046 \\
\hline \multirow{12}{*}{2022} & January & \multirow{9}{*}{350} & 50 & & 31 & 81 & 966 \\
\hline & February & & 50 & & 31 & 81 & 885 \\
\hline & March & & 50 & & 31 & 81 & 804 \\
\hline & April & & 50 & & 31 & 81 & 723 \\
\hline & May & & 50 & & 31 & 81 & 642 \\
\hline & June & & 50 & & 31 & 81 & 911 \\
\hline & July & & 50 & & 31 & 81 & 830 \\
\hline & August & & 50 & & 31 & 81 & 749 \\
\hline & September & & 50 & & 31 & 81 & 668 \\
\hline & October & \multirow{3}{*}{482} & 50 & & 31 & 81 & 587 \\
\hline & November & & 50 & & 31 & 81 & 506 \\
\hline & December & & 50 & & 31 & 81 & 907 \\
\hline
\end{tabular}

*The rabi and kharif procurement in 2021 and 2022 is assumed to be the average of 2018-19 and 2019-20 of 35 and 48 million metric tonnes respectively

**Estimated NFSA distribution includes allocation for the PDS along with foodgrains for the Integrated Child Development Scheme (ICDS), Mid-day Meal (MDM) and other legal commitments under the law (Monthly Food Grain Bulletin.

***The government announced that 5 kilograms of free foodgrain would be provided to all NFSA beneficiaries till November 2021 under the PMGKAY.

\#Population projections for 2021 and 2022 based on (Census of India, 2019)

\#\#Only for August 2021, the current FCI stock is calculated as the existing stock of rice, wheat and paddy in the FCI godown at the beginning of the month as per the FCI website. For unmilled paddy CMR is calculated based on an outturn ratio of $67 \%$.

Even though the government has extended the PMGKAY which provides 5 kilograms of additional free foodgrains to current NFSA ration cardholders till November 2021, this research indicates that there is still more than sufficient foodgrain stock to simultaneously universalise the public distribution system, to provide 5 kilograms of foodgrains to those without ration cards. In fact, with exceptionally good rains and despite the lockdown, in June 2021 there was bumper rabi 
wheat harvest. The procurement of wheat was the highest ever recorded of 43 million tonnes (PIB, 2021). Nevertheless, for this research the foodgrain availability projections for 2021 and 2022 have been maintained at extremely conservative levels, to avoid unrealistic future expectations. The procurement for the rabi and kharif season are assumed to be the average of the previous two years with full estimates i.e. 2018-19 and 2019-20 of 35 and 48 million metric tonnes respectively. Further, the government always has the possibility, in future, of increasing the minimum support price (MSP) provided to farmers to increase procurement. From 2017 to 2020, FCI procurement averaged at only around 32-37 per cent of the annual harvests, with ample scope for expansion.

Population projections for 2021 and 2022 also indicate that around 600 million Indians respectively, would be without NFSA rations cards unless there is an upward revision of population estimates. The assumption for this research on universal coverage is that each of these excluded persons, except income tax payers, will be provided with 5 kilograms of foodgrain each month from September 2021 onwards. Thus, projections of foodgrain procurement and stocks indicate that, the universal expansion of the PDS is undoubtedly viable in terms of availability of foodgrains.

\section{Demand Side: Chronic hunger and vulnerable communities}

But in 2013, the food law guaranteed subsidised food grains to only 800 million Indians or twothirds of India's population. However, due to rapid growth, India's population is projected to have reached 1.36 billion by 2021. But, despite economic growth ration cards lists have not been updated in the last decade, at least 100 million eligible persons are estimated to be out of its ambit (Scroll, 2020). Of these the majority may be children under the age of 10 years born after the 2011 Census. Further, the process of selection of beneficiaries has always been plagued with targeting errors (Drèze et al., 2017; Khera, 2015). The insistence on linkage with the national unique identity number, aadhaar, has also deprived scores of genuine beneficiaries (Muralidharan et al., 2020).

Further, as NFSA ration cards have not been increased despite rapid population expansion, based on projections for 2021, this research estimates that 42 per cent of India's population is effectively excluded from NFSA ration cards (see Table 2). Urbanised and wealthier states such as Goa and those in north-east India, have the largest proportions of left-out populations. However, poorer states such as Bihar and Jharkhand have greater exclusions in terms of the absolute number of people outside the NFSA ambit. 


\begin{tabular}{|c|c|c|c|c|c|c|c|}
\hline \multicolumn{8}{|c|}{ Table 2: Estimated Population Excluded from NFSA Ration Cards 2021 (in 000s) } \\
\hline & & $\begin{array}{c}\text { Antyodaya } \\
\text { Anna } \\
\text { Yojana } \\
\text { (AAY) } \\
\text { Beneficiarie } \\
\text { s }\end{array}$ & $\begin{array}{l}\text { Priority }(\mathrm{PH}) \\
\text { Beneficiaries }\end{array}$ & $\begin{array}{c}\text { Total National } \\
\text { Food Security } \\
\text { Act (NFSA) } \\
\text { Beneficiaries* }\end{array}$ & $\begin{array}{c}\text { Projected } \\
\text { Population } \\
(2021)^{* *}\end{array}$ & $\begin{array}{c}\text { Population } \\
\text { without } \\
\text { NFSA ration } \\
\text { cards } \\
(2021)\end{array}$ & $\begin{array}{c}\text { Populatio } \\
\text { n without } \\
\text { NFSA } \\
\text { ration } \\
\text { cards (\%) }\end{array}$ \\
\hline \multirow{5}{*}{ ż̃ } & Bihar & 11680 & 75588 & 87269 & 123083 & 35814 & 29 \\
\hline & Haryana & 998 & 11252 & 12252 & 29483 & 17231 & 58 \\
\hline & Himachal Pradesh & 727 & 2103 & 2744 & 7394 & 4650 & 63 \\
\hline & Punjab & 352 & 14727 & 14963 & 30339 & 15376 & 51 \\
\hline & Uttarakhand & 674 & 5376 & 5964 & 11399 & 5435 & 48 \\
\hline \multirow{5}{*}{ 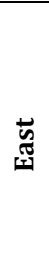 } & Chhattisgarh & 1992 & 18278 & $2,02,73$ & 29493 & 9220 & 31 \\
\hline & Jharkhand & 3635 & 22489 & 26153 & 38471 & 12318 & 32 \\
\hline & Odisha & 3812 & 28620 & 32328 & 45696 & 13368 & 29 \\
\hline & Uttar Pradesh & 13025 & 135088 & 147776 & 230907 & 83131 & 36 \\
\hline & West Bengal & 5487 & 54688 & $6,01,75$ & 98125 & 37950 & 39 \\
\hline \multirow{5}{*}{$\sum^{\vec{y}}$} & Goa & 45 & 500 & 545 & 1559 & 1014 & 65 \\
\hline & Gujarat & 3670 & 31120 & 34802 & 69788 & 34986 & 50 \\
\hline & Madhya Pradesh & 5881 & 41129 & 47010 & 84516 & 37506 & 44 \\
\hline & Maharashtra & 10712 & 57168 & 67667 & 124437 & 56770 & 46 \\
\hline & Rajasthan & 2386 & 42044 & 44572 & 79281 & 34709 & 44 \\
\hline \multirow{5}{*}{ 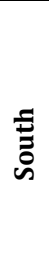 } & Andhra Pradesh & 2475 & 24284 & 26758 & $5,27,87$ & 26028 & 49 \\
\hline & Telangana & 1540 & $1,76,29$ & $1,91,69$ & $3,77,25$ & 18556 & 49 \\
\hline & Karnataka & 4620 & 35643 & 40784 & 66845 & 26061 & 39 \\
\hline & Kerala & 2216 & 13156 & 15390 & 35489 & 20099 & 57 \\
\hline & Tamil Nadu & 6689 & 29594 & 36432 & 76402 & 39969 & 52 \\
\hline \multirow{8}{*}{ 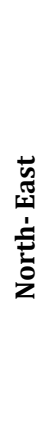 } & Arunachal Pradesh & 150 & 694 & 844 & 1533 & 689 & 45 \\
\hline & Assam & 2808 & 22309 & 25117 & 35043 & 9926 & 28 \\
\hline & Manipur & 1767 & 1684 & 1860 & 3165 & 1305 & 41 \\
\hline & Meghalaya & 291 & 1854 & 2145 & 3288 & 1143 & 35 \\
\hline & Mizoram & 71 & 608 & 683 & 1216 & 533 & 44 \\
\hline & Nagaland & 158 & 910 & 1098 & 2192 & 1093 & 50 \\
\hline & Sikkim & 58 & 316 & 374 & 677 & 303 & 45 \\
\hline & Tripura & 475 & 1996 & 2469 & 4071 & 1602 & 39 \\
\hline \multirow{8}{*}{ 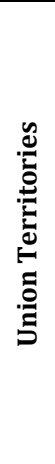 } & $\begin{array}{l}\text { Andaman and } \\
\text { Nicobar Islands }\end{array}$ & 13 & 47 & 60 & 400 & 340 & 85 \\
\hline & Chandigarh & 663 & 283 & 286 & 1208 & 922 & 76 \\
\hline & $\begin{array}{l}\text { Dadra and Nagar } \\
\text { Haveli }\end{array}$ & 20 & 182 & 202 & 608 & 406 & 67 \\
\hline & Daman and Diu & 4 & 183 & 68 & 469 & 401 & 86 \\
\hline & Delhi & 281 & 7042 & 7321 & 20571 & 13250 & 64 \\
\hline & $\begin{array}{l}\text { Jammu and } \\
\text { Kashmir with } \\
\text { Ladakh }\end{array}$ & 900 & 5646 & 6635 & 13705 & 7070 & 52 \\
\hline & Lakshadweep & 4 & 18 & 22 & 67 & 45 & 67 \\
\hline & Puducherry & 83 & 550 & 631 & 1571 & 940 & 60 \\
\hline \multicolumn{2}{|c|}{ Total (All India) } & 90362 & 682859 & 792841 & 1363004 & 570162 & 42 \\
\hline
\end{tabular}


Source: Author Calculations

Note: *NFSA, Priority and Antyodaya Anna Yojana Beneficiaries based on NFSA Dashboard at the National Food

Security Portal of the Department of Food and Public Distribution of the Government of India,

https://nfsa.gov.in/public/nfsadashboard/PublicRCDashboard.aspx (last checked 9 June 2021)

**Projected 2021 population is based on 'Population Projections for India and the States 2011-2036 based on Census 2011, Report of the Technical Group on Population Projections' of the National Commission of Population in the Ministry of Health and Family Welfare, released in July 2020

Further, only some states such as Odisha, Chhattisgarh, Rajasthan, West Bengal, Tamil Nadu and Himachal Pradesh have invested their own state finances to expand or universalise coverage. However, populous states with high levels of poverty such as Bihar, Jharkhand, Uttar Pradesh and Madhya Pradesh have not been able to effectively expand their food distribution systems. During different phases of lockdowns their populations without any ration cards, have been the most affected.

In this context, amongst the many excluded populations, two communities most impacted by the lockdown were internal migrants and vulnerable women (see Table 3). In most cases, within these broader categorizations, marginalised castes, tribes, ethnicities and religions have been the most affected.

\begin{tabular}{|c|c|c|c|c|}
\hline $\begin{array}{l}\begin{array}{l}\text { Name of } \\
\text { or }\end{array} \quad \text { Learvey } \\
\text { Organisation }\end{array}$ & Period & Sample & Main Findings & Reference \\
\hline $\begin{array}{l}\text { Azim Premji } \\
\text { University }\end{array}$ & $\begin{array}{l}\text { April and } \\
\text { May } 2020\end{array}$ & 12 states & $\begin{array}{l}77 \text { percent of households self- } \\
\text { reported consuming less food and } \\
47 \text { percent of the households did } \\
\text { not have money to even buy a } \\
\text { week's worth of essentials }\end{array}$ & (APU, 2020) \\
\hline $\begin{array}{l}\text { Stranded Workers } \\
\text { Action Network }\end{array}$ & $\begin{array}{l}\text { May } 15 \text { and } \\
\text { June } 1,2020\end{array}$ & $\begin{array}{l}5911 \text { migrant } \\
\text { workers } \\
\text { nationwide }\end{array}$ & $\begin{array}{l}50 \text { per cent of migrant workers } \\
\text { interviewed had rations left for less } \\
\text { than a day. In Maharashtra, } 71 \text { per } \\
\text { cent had rations only for a day while } \\
89 \text { per cent had stocks for two days. } \\
96 \text { per cent of the surveyed workers } \\
\text { had not received ration from the } \\
\text { government and } 70 \text { per cent had } \\
\text { not got any cooked food. }\end{array}$ & (SWAN, 2020) \\
\hline Indus Action & $\begin{array}{l}\text { April - May } \\
2020\end{array}$ & 15 states & $\begin{array}{l}\text { One of every six households } \\
\text { indicated that they were in need of } \\
\text { food. } 30 \text { percent of households } \\
\text { eligible for rations, were denied } \\
\text { their entitlements. } 40 \text { percent of } \\
\text { women surveyed reported that } \\
\text { they were either not able to access } \\
\text { these cash transfer or were } \\
\text { unaware of its status }\end{array}$ & $\begin{array}{l}\text { (Indus Action, } \\
\text { 2020; Patel et al., } \\
\text { 2020) }\end{array}$ \\
\hline
\end{tabular}




\begin{tabular}{|c|c|c|c|c|}
\hline $\begin{array}{l}\text { VAF and } \\
\text { Samboodhi }\end{array}$ & $\begin{array}{l}\text { June-July } \\
2020\end{array}$ & $\begin{array}{l}11 \quad \text { states } \\
\text { especially } \\
\text { migrants }\end{array}$ & $\begin{array}{l}29 \text { percent of migrants had } \\
\text { managed to return back to } \\
\text { industrial cities for want of skilled } \\
\text { work in villages and } 45 \text { percent of } \\
\text { those in rural areas were also } \\
\text { equally eager to return }\end{array}$ & $\begin{array}{l}\text { (VAF } \\
\text { Samboodhi, } \\
\text { 2020). }\end{array}$ \\
\hline Hunger Watch & $\begin{array}{l}\text { October } \\
2020\end{array}$ & 11 states & $\begin{array}{l}54 \text { percent of respondents in urban } \\
\text { cities and towns had to borrow } \\
\text { money for food, compared to } 38 \\
\text { percent in rural villages. } 60 \text { percent } \\
\text { of Muslims, } 51 \text { percent of dalits, } 58 \\
\text { per cent of the elderly without } \\
\text { caregivers and } 56 \text { per cent of single } \\
\text { women-headed households went to } \\
\text { bed without a meal at least once in } \\
\text { that month }\end{array}$ & $\begin{array}{l}\text { RTFC \& CES, } \\
\text { 2021) }\end{array}$ \\
\hline SEWA & $\begin{array}{l}\text { Two months } \\
\text { after the } \\
\text { lockdown }\end{array}$ & $\begin{array}{l}12 \text { states in } \\
\text { women in } \\
\text { informal sector }\end{array}$ & $\begin{array}{l}91 \text { percent of their women } \\
\text { members had borrowed money } \\
\text { from extended family and only half } \\
\text { had received food rations from the } \\
\text { government despite } 70 \text { percent } \\
\text { being in possession of a ration card }\end{array}$ & $\begin{array}{l}\text { (SEWA Bharat, } \\
\text { 2020). }\end{array}$ \\
\hline YUVA & $\begin{array}{l}\text { early days of } \\
\text { the } \\
\text { pandemic }\end{array}$ & $\begin{array}{l}700 \text { respondents } \\
\text { in Mumbai with } \\
\text { homeless and } \\
\text { transgender } \\
\text { people }\end{array}$ & $\begin{array}{l}\text { Homeless and trans people who } \\
\text { depended on alms for a living were } \\
\text { being increasingly shunned, } \\
\text { discriminated against and were } \\
\text { more impoverished than before }\end{array}$ & (YUVA, 2020) \\
\hline $\begin{array}{l}\text { All India Network } \\
\text { of Sex Workers } \\
\text { (AINSW) }\end{array}$ & May 2020 & Sex workers & $\begin{array}{l}60 \text { percent of registered sex } \\
\text { workers had returned to their } \\
\text { villages as they faced imminent } \\
\text { starvation without work or access } \\
\text { to any form of government food } \\
\text { entitlements }\end{array}$ & $\begin{array}{l}\text { (Seshu et al., } \\
2015 \text { ) and other } \\
\text { sources }\end{array}$ \\
\hline $\begin{array}{l}\text { Mahila Kisan } \\
\text { Adhikaar } \\
\text { Manch (MAKAAM) }\end{array}$ & $\begin{array}{l}\text { March-April } \\
2020\end{array}$ & $\begin{array}{lr}\text { Women } & \text { farmers } \\
\text { across } & 14 \\
\text { districts } & \text { of } \\
\text { Maharashtra } & \\
\end{array}$ & $\begin{array}{l}30 \text { percent of single women were } \\
\text { excluded from the PDS as they did } \\
\text { not possess ration cards }\end{array}$ & (Kulkarni, 2020) \\
\hline
\end{tabular}

\subsection{Internal Migrants}

In the first wave of the pandemic, the Prime Minister announced the abrupt nationwide lockdown from 25th March 2020 with only four hours' notice. This triggered unprecedented distressinduced reverse migration from cities to villages, the largest in the India's history since the 1947 Partition. Consequently more than 20 million internal migrants (Singh \& Magazine, 2020) are estimated to have defied lockdown orders to traverse hundreds of kilometres from industrial cities to distant villages.

Thirty-six hours after this shutdown the government introduced the PMGKAY, with a few food security initiatives. However, the package increased entitlements only for existing NFSA beneficiaries. But most migrant labourers either do not possess ration cards or leave them behind in their villages for their families. After three months, the government finally announced the Atma Nirbhar package aimed to provide a one-off grant of 10 kilograms of food grains to 80 million migrant labourers without ration cards. But due to excessively centralised quotas and insistence 
on identity proof, despite an extension, only 33 per cent of the allocated foodgrains for migrants was distributed (Sharma, 2020).

However, the most publicised initiative was the 'One Nation One Ration' (ONOR) scheme to enable migrants to purchase subsidised food grains in any destination, is however only restricted to only those with NFSA ration cards. As per the government's Integrated Management of Public Distribution System (IM-PDS) database, in September 2021 nationwide less than 14,000 (0.005 percent) ration cards employed ONOR. In the second wave the situation has become so dire, that the Supreme Court on 13 May 2021 and various High Courts had to order state govenrments to set up community kitchens for migrants.

\subsection{Vulnerable Women}

More than half of Indian women are anaemic (NFHS, 2017). Typically, the intra-household distribution of food acutely discriminates against women, who eat last at family meals (Coffey et al., 2015). Especially during times of food scarcity, nutritional consumption of women deteriorates with age within Indian households (Shivkumar \& Kerbart, 2004). However, the lockdown policies initiated by the government were restricted to a modest cash transfer $(\$ 6.7$ per month only) in 200 million women's Jan Dhan bank accounts for only three months. However, numerous surveys indicate that women were either not able to access this cash transfer or were unaware of its status (Indus Action, 2020; Patel et al., 2020). Despite being in possession of ration cards, many women also struggled to gain access to their food entitlements (SEWA Bharat, 2020).

Further, trans people, sex workers and homeless people who depended on alms for a living were being increasingly shunned, with limited access to any food security or livelihoods (YUVA, 2020). Eventually in September 2020, based on a writ, the Supreme Court ordered that all states should provide rations, without identity proof, to all recognised sex workers. Single women especially those with from particularly vulnerable tribal groups (PVTGs) and denotified and nomadic tribes (DNTs) were also more likely to be excluded from ration cards (Kulkarni, 2020). The 2020 Hunger Watch survey also found that single women-headed households were more likely to be hungry (RTFC \& CES, 2021).

\section{Summary and Conclusion: Time for universal food entitlements}

One of every four of the world's undernourished people live in India (FAO, 2020). In no other country in the world has an mismanaged COVID-19 lockdown, triggered a humanitarian crisis 
with an exodus of migrants. Besides, even before the pandemic, India already had unprecedented levels of unemployment and recession.

The pandemic has further exposed and exacerbated the inequalities in India's food entitlements infrastructure, as only those with existing ration cards have benefitted. India also is expected to have the largest population impoverished due to the pandemic (World Bank, 2020). However, the central government has spent less than 3 percent of GDP as a fiscal stimulus for food subsidy. This minimalistic support has proven to be sorely inadequate to protect vulnerable communities from food insecurity.

Therefore, a perceptible need exists to universalise food entitlements to ensure that especially those with 'intersectional vulnerabilities' including internal migrants and vulnerable women from marginalised communities are effectively protected from impoverishment. Even before the pandemic, studies had recommended universal allocation of nutritious foodgrains each month (Jha and Acharya 2013).

Therefore, with an historic record of food grains stocks currently in government granaries, the time is ripe for the universal expansion the public distribution system. 


\section{References}

Aman, Sharma, K., Thejesh, G., \& Krushna. (2020, April 1). Non Virus Deaths.

https://thejeshgn.com/projects/covid19-india/non-virus-deaths/

APU. (2020). COVID-19 Livelihoods Survey Compilation of findings. Azim Premji University.

https://cse.azimpremjiuniversity.edu.in/wp-content/uploads/2020/06/Compilationof-findings-APU-COVID-19-Livelihoods-Survey_Final.pdf

APU. (2021). State of Working India: One year of Covid-19. Centre for Sustainable Employment, Azim Premji University. https://cse.azimpremjiuniversity.edu.in/wpcontent/uploads/2021/05/SWI2021_May12.pdf

Banik, D. (2016). The Hungry Nation: Food Policy and Food Politics in India. Food Ethics, 1(1), 29-45. https://doi.org/10.1007/s41055-016-0001-1

Bardhan, P., \& Mookherjee, D. (2005). Decentralizing antipoverty program delivery in developing countries. Journal of Public Economics, 89(4), 675-704. https://doi.org/10.1016/j.jpubeco.2003.01.001

Bedamatta, R. (2016). Two Decades of Geographical Targeting in Food Distribution: Drawing Lessons from an Indian State. Indian Journal of Human Development, 10(3), 366-383. https://doi.org/10.1177/0973703017698892

Bhatia, R. (2018, May 16). How India's Welfare Revolution Is Starving Citizens. The New Yorker. https://www.newyorker.com/news/dispatch/how-indias-welfare-revolution-isstarving-citizens

Bhattacharya, D. (2020, March 7). Jharkhand: Day after Government Denies Phenomenon in Assembly, Another Starvation Death. NewsClick. https://www.newsclick.in/jharkhandday-government-denies-phenomenon-assembly-starvation-death

Census of India. (2019). Population Projections for India and States, 2011 - 2036 [Report of the Technical Group on Population Projections]. National Commission on Population, Ministry of Health and Family Welfare. https://nhm.gov.in/New_Updates_2018/Report_Population_Projection_2019.pdf 
Chatterjee, M. (2014). An Improved PDS in a "Reviving" State: Food Security in Koraput, Odisha. Economic and Political Weekly, 49(45), 49-59.

Chaudhuri, B., Janani, A., \& Hundal, H. S. (2015). A Conundrum of Efficiency And Inclusion: Aadhaar and Fair Price Shops. Economic and Political Weekly, EPW Engage, 7-8.

Coffey, D., Hathi, P., Khurana, N., \& Thorat, A. (2015). Explicit Prejudice: Evidence from a New Survey. Economic and Political Weekly, 53(1), 46-54.

Das, D., \& Basu, D. (2014). Social Hierarchies and Public Distribution of Food in Rural India. University of Massachusetts Amherst. https://core.ac.uk/reader/32436080

Davis, K. (2008). Intersectionality as buzzword: A sociology of science perspective on what makes a feminist theory successful. Feminist Theory. https://doi.org/10.1177/1464700108086364

Deshpande, A., \& Ramachandran, R. (2020). Which Indian Children are Short and Why? Social Identity, Childhood Malnutrition and Cognitive Outcomes. In Working Papers (No. 27; Working Papers). Ashoka University, Department of Economics. https://ideas.repec.org/p/ash/wpaper/27.html

Drèze, J. (2020, June 9). Averting hunger during monsoon calls for bold food security measures. The Indian Express. https://indianexpress.com/article/opinion/columns/nrega-fundsmigrant-workers-monsoon-pds-scheme-6449293/

Drèze, J., Gupta, P., Khera, R., \& Pimenta, I. (2015). Casting the Net: India's Public Distribution System after the Food Security Act. Economic and Political Weekly, 54(6), 7-8.

Drèze, J., Khalid, N., Khera, R., \& Somanchi, A. (2017). Aadhaar and Food Security in Jharkhand: Pain without Gain? | Economic and Political Weekly. Economic and Political Weekly, $\operatorname{LII}(50), 50-60$.

Drèze, J., \& Sen, A. (1989a). Hunger and Public Action. Oxford University Press.

Drèze, J., \& Sen, A. (1989b). Public Action for Social Security: Foundations and Strategy. In Social Security in Developing Countries. Oxford University Press. 
https://www.oxfordscholarship.com/view/10.1093/acprof:oso/9780198233008.001.0 001/acprof-9780198233008-chapter-1

Drèze, J., \& Sen, A. (2002). India: Development and Participation. Oxford University Press.

Dutta, B., \& Ramaswamy, B. (2001). Targeting and Efficiency in the Public Distribution System: Case of Andhra Pradesh and Maharashtra. Economic and Political Weekly, 36(18), 15241532.

Esping-Andersen, G. (1989). The Three Worlds of Welfare Capitalism. Polity Press.

FAO. (2020). The State of Food Security and Nutrition in the World 2020. Food and Agriculture Organization of the United Nations. https://doi.org/10.4060/CA9692EN

FAOSTAT. (2019). Number of People Undernourished (millions), Suite of Food Security Indicators 2018-2020. Food and Agricultural Organisation. http://www.fao.org/faostat/en/\#data/FS

Hale, T., Webster, S., Petherick, A., Phillips, T., \& Kira, B. (2020). The Oxford Covid-19 Government Response Tracker (OxCGRT). Blavatnik School of Government, University of Oxford. https://covidtracker.bsg.ox.ac.uk/

Hirschman, A. O. (1970). Exit, Voice, and Loyalty: Responses to Decline in Firms, Organizations, and States. Harvard University Press.

Hirway, I. (2003). Identification of BPL Households for Poverty Alleviation Programmes. Economic and Political Weekly, 38(45), 4803-4808.

Hussain, S., \& Mohapatra, J. (2021, April 10). Once Again, the Centre Has Excess Wheat, Rice Stocks. What Are Its Options? The Wire. https://thewire.in/agriculture/once-again-thecentre-has-excess-wheat-rice-stocks-what-are-its-options

Hussain, S., \& Ranade, A. (2020, May 6). Diverting rice to produce ethanol during pandemic is unethical. The Indian Express. https://indianexpress.com/article/opinion/columns/riceto-produce-ethanol-hand-sanitisers-coronavirus-6395644/

IIPS and MoHFW. (2020). National Family Health Survey (NFHS-5) Fact-Sheets: Key Indicators 22 States/UTs From Phase-I. http://rchiips.org/nfhs/factsheet_NFHS-5.shtml 
Indus Action. (2020). Indus Action Rapid Survey: Status of welfare delivery during lockdown in India (April-May 2020). Indus Action.

Johari, A. (2018). A year after Jharkhand girl died of starvation, Aadhaar tragedies are on the rise, Scroll; https://scroll.in/article/895667/a-year-after-jharkhand-girl-died-of-starvationaadhaar-tragedies-are-on-the-rise

Khera, R. (2009). “Right to Food” Act: Beyond Cheap Promises. Economic and Political Weekly, 44(29), 40-44.

Khera, R. (2015). Impact of Aadhaar on Welfare Programmes. Economic and Political Weekly, $52(50), 7-8$.

Kochar, A. (2005). Can Targeted Food Programs Improve Nutrition? An Empirical Analysis of India's Public Distribution System. Economic Development and Cultural Change, 54(1), 203-235. JSTOR. https://doi.org/10.1086/431260

Kulkarni, S. (2020). Locked in a Crisis: Concerns of Rural Women. Economic and Political Weekly, 55(23), 7-8.

Leach, M., MacGregor, H., Scoones, I., \& Wilkinson, A. (2021). Post-pandemic transformations: How and why COVID-19 requires us to rethink development. World Development, 138, 105233. https://doi.org/10.1016/j.worlddev.2020.105233

Muralidharan, K., Niehaus, P., \& Sukhtankar, S. (2020). Identity Verification Standards in Welfare Programs: Experimental Evidence from India (Working Paper No. 26744; Working Paper Series). National Bureau of Economic Research. https://doi.org/10.3386/w26744

Narayan, S. (2016). Towards Equality in Healthcare: Trends Over Two Decades. Economic and Political Weekly, 51(12). https://www.epw.in/author/swati-narayan

NCAER. (2015). Evaluation Study of Targeted Public Distribution System in Selected States. National Council of Applied Economic Research for the Department of Food and Public Distribution Ministry of Consumer Affairs, Food and Public Distribution, Government of India. https://dfpd.gov.in/1sGbO2W68mUlunCgKmpnLF5WHm/TPDS-140316.pdf 
NFHS. (2017). National Family Health Survey 4, 2015-16. International Institute of Population Sciences.

Ocampo, J. A., \& Stiglitz, J. E. (2018). The Welfare State Revisited. Columbia University Press.

Patel, A., Divakar, P., \& Prabhakar, R. (2020, June 29). 40\% Of Jan Dhan Account Holders Could Not Access Govt's COVID-19 Relief: Survey. Indiaspend. https://www.indiaspend.com/40of-jan-dhan-account-holders-could-not-access-govts-covid-19-relief-survey/

PIB. (2021, July 5). Record wheat procurement of 433.24 LMT undertaken in RMS 2021-22 surpassing previous best of 389.93 LMT. Press Information Bureau, Ministry of Consumer Affairs, Food \& Public Distribution.

https://pib.gov.in/PressReleseDetail.aspx?PRID=1732864

Rahman, A. (2016). Universal food security program and nutritional intake: Evidence from the hunger prone KBK districts in Odisha. Food Policy, 63, 73-86. https://doi.org/10.1016/j.foodpol.2016.07.003

RTFC, \& CES. (2021). Hunger Watch Report. Right to Food Campaign and Centre for Equity Studies.

Scroll. (2020, April 15). 100 million Indians fall through gaps in food safety net, economists urge rethink on Covid-19 relief. Scroll; https://scroll.in. https://scroll.in/article/959235/100million-indians-fall-through-gaps-in-food-safety-net-economists-urge-rethink-on-covid19-relief

Sen, A. (1992). The Political Economy of Targeting. In Public Spending and the Poor (eds. D. van de Walle and K. Nead). World Bank.

https://scholar.harvard.edu/sen/publications/political-economy-targeting

Sen, A. (2003). Development as Capability Expansion. In S. Fukuda-Parr, A. K. Shiva Kumar, S. Fukuda-Parr, \& A. K. Shiva Kumar (Eds.), Readings in human development: Concepts, measures and policies for a development paradigm. Oxford University Press.

Seshu, M. S., Pai, A., \& Murthy, L. (2015). Locked Down: Sex Workers and Their Livelihoods. Economic and Political Weekly, 7-8. 
SEWA Bharat. (2020). Gendered precarity in the lockdown: What the lockdown shows us about the precarity of women workers (p. 11). SEWA Bharat: All India Federation of Self-Employed Women's Association.

Sharma, H. (2020, September 2). Atma Nirbhar Bharat package: Only 33 per cent of foodgrains allocated for migrants distributed. The Indian Express. https://indianexpress.com/article/india/atma-nirbhar-bharat-package-only-33-percent-of-foodgrains-allocated-for-migrants-distributed-6579390/

Shivkumar, S., \& Kerbart, E. (2004). Drought, Sustenance and Livelihoods. Economic and Political Weekly, 39(3). https://www.epw.in/journal/2004/03/special-articles/droughtsustenance-and-livelihoods.html

Singh, S., \& Magazine, A. (2020, April 29). Explained: Indian migrants, across India. The Indian Express. https://indianexpress.com/article/explained/coronavirus-india-lockdownmigran-workers-mass-exodus-6348834/

Skocpol, T. (1991). Universal Appeal: Politically Viable Policies to Combat Poverty. The Brookings Review, 9(3), 28-33.

Sumner, A., Ortiz-Juarez, E., \& Hoy, C. (2020). Precarity and the pandemic: COVID-19 and poverty incidence, intensity, and severity in developing countries (WIDER Working Paper 77/2020). UNU-WIDER. https://www.wider.unu.edu/publication/precarity-andpandemic

Sundaram, K. (2003). On Identification of Households below Poverty Line in BPL Census 2002. Economic and Political Weekly, 39(9), 7-8.

Swaminathan, M. (2002). Excluding the Needy: The Public Provisioning of Food in India. Social Scientist, 30(3/4), 34-58. JSTOR. https://doi.org/10.2307/3518075

Swaminathan, M., \& Misra, N. (2001). Errors of Targeting: Public Distribution of Food in a Maharashtra Village, 1995-2000. Economic and Political Weekly, 36(26). https://www.epw.in/journal/2001/26/special-articles/errors-targeting.html 
SWAN. (2020). 21 Days and Counting:COVID-19 Lockdown, Migrant Workers, and the Inadequacy of Welfare Measures in India. Stranded Workers Action Network.

VAF, \& Samboodhi. (2020). How is the hinterland unlocking? Findings from 2 nd round of survey. VikasAnvesh Foundation and Samboodhi. https://villagesquare.in/webinar/wpcontent/uploads/2020/08/VAF-CSO-Covid19-survey-round-2-3-8-20-webinarslides_Kiran-Limaye.pdf

World Bank. (2020, June 8). Projected poverty impacts of COVID-19 (coronavirus). Updated Estimates of the Impact of COVID-19 on Global Poverty. https://blogs.worldbank.org/opendata/updated-estimates-impact-covid-19-globalpoverty

YUVA. (2020, March 26). Rapid situation analysis of the state of the urban poor in Greater Mumbai during the COVID-19 pandemic. Medium. https://medium.com/@yuvaonline/rapid-situation-analysis-of-the-state-of-the-urbanpoor-in-greater-mumbai-during-the-covid-19-65981d7df857 